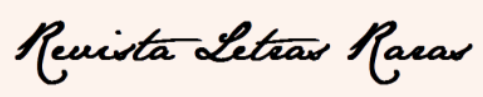

ISSN: $2317-2347$ - v. 8, n. 1 (2019)

\title{
Editorial
}

Revista Letras Raras, periódico acadêmico de Língua e Literatura v. 8, n. 1. 2019

\section{Estudos de Letras e Linguagens na contemporaneidade}

Iniciando o seu oitavo ano, este periódico acadêmico permanece no seu propósito inicial de partilhar a produção intelectual de pesquisadores originada em pesquisas de em nível de graduação e pós-graduação. Neste primeiro número de 2019, temos a oportunidade de publicar a segunda edição integralmente bilingue, o que resulta de um árduo trabalho, que busca ampliar para além das fronteiras nacionais as partilhas proporcionadas pelos colegas de diversos espaços do nosso país e do exterior.

Neste número, o comitê editorial apresenta uma edição atemática; no entanto, completamente dentro do domínio dos estudiosos das Letras, haja vista que é também política editorial deste periódico publicar artigos sem uma temática específica. Nesta edição, todos os artigos estão ligados aos Estudos de Letras e Linguagens na contemporaneidade. A exemplo das edições anteriores, nesta também o leitor poderá ler artigos que trazem imprescindíveis reflexões, com bases teóricas sólidas, ancoradas no nosso domínio das Letras, tanto para a área da linguística, quanto para a da literatura, passando pelo discurso e ainda pela tradução, em artigos de estudiosos de diversas instituições de ensino superior e de institutos federais brasileiros.

As organizadoras deste número, que é atemático, mas que giram em torno dos Estudos de Letras e Linguagens na contemporaneidade, contaram com colegas pesquisadores atuantes em programas de Pós-Graduação do Brasil e do exterior como leitores e pareceristas dos artigos, trazendo ao público leitor resultados de investigações que impactam pela sua importância para os estudos em seus domínios de atuação. Os artigos que receberam aceite de dois pareceristas, seguindo a política editorial de leitura e avaliação às cegas, vêm agora a público, após um tratamento que passa por fases distintas e progressiva, desde a avaliação do comitê editorial, quanto à detecção de plágio, chegando à etapa final que consta da revisão dos textos na língua inglesa. Porém, entre uma etapa e outra, há diversas outras que incluem um vai e vem de textos lidos, pareceres, avaliações, ajustes, revisão de língua portuguesa, versão final do texto para o inglês, até, finalmente, chegar ao ponto de estar apto a chegar às mãos da editoração para, enfim, ser publicado.

Em um processo iniciado ainda em 2018, quando se decidiu por fazer a revista bilingue, o intento de alcançar um maior público tem se confirmado com o número significativo de visitantes em todos os continentes, conforme podemos consultar no Visitor Map for Revistas.ufcg.edu.br/ch/. Constatamos, dessa forma, que a missão deste periódico vai se confirmando a cada publicação e o impacto dos artigos acadêmicos vai ultrapassando fronteiras continentais.

É assim, caro leitor que, nós, os editores deste periódico acadêmico, iniciamos este ano de 2019, com o propósito de fazer a Revista Letras Raras ... caminhar, circulando o conhecimento!

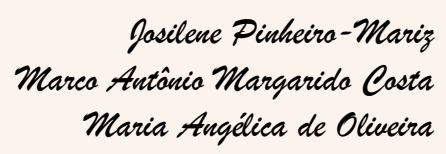

Editores da Revista Letras Raras, periódico Acadêmico do grupo de pesquisa LELLC-

Laboratório de Estudos de Letras e Linguagens na Contemporaneidade, da Universidade Federal de Campina Grande. 